\title{
CLARIFICATION OF SASA GOURMET POWDER ADVERTISEMENT TOWARDS INDONESIAN PERCEPTIONS: A DISCOURSE ANALYSIS
}

\author{
Jauhar Helmie ${ }^{1}$, Arsyi Fadilah Al khoeri ${ }^{2}$, \\ Euis Nursifa Laila Nugraha ${ }^{3}$, Tassya Salsabila Ramadhiani ${ }^{4}$ \\ jauharhelmie@unsur.ac.id ${ }^{1}$, \\ arsyialkhoeri@gmail.com ${ }^{2}$ \\ euisnursifalailanugraha21@gmail.com ${ }^{3}$ \\ tassyatassyasr@gmail.com ${ }^{4}$
}

Suryakancana University

\begin{abstract}
This research describes the advertisement of Sasa Gourmet Powder which clarify issues that develop in Indonesian society about the use of MSG that is harmful for health. The source data used in this research is a "Sasa Gourmet Powder Advertisement \#NikmatiHidupSepenuhnya (2021)" which has 29 seconds in long. The advertisement selected is available on Youtube. The aims of this research to reveal the purpose about why this advertisement is made and the social conditions underlying the making of the advertisement. This research applies descriptive qualitative method, which describes and explains the social world phenomenon or events. One of types in qualitative research is text analysis. This research utilizes text analysis in Sasa Gourmet Powder using Discourse analysis approach. The theory that used in this research is about ThreeDimensional Approach by Fairclough (1995). This theory explain about the relationship exists between social structures and discourse, because discourse influences social conventions, while social structures influence discourse. It focuses on analysis of language text, discourse practice (texts production and interpretations of text), and sociocultural practice. This research found that Sasa Gourmet Powder advertisements are designed to bring a new packaging from the company and to clarify its problems about MSG that have spread in society. With this advertisement, Sasa wants to show the fact that the MSG product does not cause stupidity. Sasa explained that its MSG products are safe to consume provided the limits of use are appropriate. Its products were also safely and halalled certified.
\end{abstract}

Keywords: Discourse analysis, Advertising discourse, Fairclough's Three-Dimensional theory, Sasa Gourmet Powder

\section{INTRODUCTION}

Technology and multimedia are the best tools in this modern society for influencing people with some products or services. This activity called as advertising. Advertising is one of the techniques which used gain the attention of people to their services or products by a company or industry (Akmal et al., 2020). Advertising builds a sense of encouragement to consumers to choose the offered products. So, consumers are first introduced to what products are being marketed, what are the benefits, and what is the difference between the products they market and 
similar products from other brands. Advertisements also try to attract customers into buying the products being marketed instead of other products.

There are many ways that advertisers persuade consumers to make interesting reports or use a language which sounds convincing and amazing. This statement was compatible with Sukamto \& Kartikawangi (2012) explanation that advertising is often packaged in language in convincing languages to influence prospective clients to purchase the services or products offered. They explain why the use of language in advertisements differs from the use of language in everyday life. The language that contained in advertising has its own purpose, which is to influence the minds of those people who see the publicity. Therefore, communication tools are needed that can support the spread of these advertising.

One of the communication tools that reach the wide community is called as mass media. It is undeniable that the marketing strategy with advertising media is still very influential on the sale of a product. It can be used to educate the public about advertising. (Sukamto \& Kartikawangi, 2012) explained that, in their capacity as a means of distributing media, mass media has functions as correlation between parts in society to respond to their environment, supervision or information seeking, and facilitator in social relations. Therefore, the mass media must be good at distributing products that going to be commercialized. In addition, the mass media must also provide education to the wider community about what they are conveying.

Advertising is currently not only used for the sale of products or services. The advertisers also have begun to use advertising to reach their brand and to convey their inserted conceptual image, music and advertising writing by using advertising rather than to promote a product (Helmie \& Syafrudin, 2019). It is inseparable from the discourse which constructs conceptions in someone else's mind when we talk about the perceptions, so we must involve social conditions and how these discourses are used in community. Execution of discourse analysis includes an examination of how language functions and the way meaning is developed in social contexts. Discourse analysis used for performing both oral and written language.

Discourse is the use of the language used in daily life. It is not only known in written form. Fairclough in (Liu \& Guo, 2016) suggests that there are three dimensions of discourse, which are text, interaction, and context respectively. He argues that the first step in dealing with the CDA is to describe the formal and structural characteristics of the text while interpreting its links with the interaction and explaining its links with the interaction and the social context is the last step. Discourse also examines the contexts of communication: with whom and why, in what society and situation; by what means; how different types and acts of communication have developed and how they relate to one another.

Most researchers have investigated about advertisement analysis by using discourse. One of them are the research with the title "Discourse Analysis of Shopee "12.12. Birthday Sale" Advertisement" by Lestari (2020). The author uses Fairclough's (1995) three-dimensional theory of speech analysis, and Wilfred's (1962) proposed connotative meaning of colour. Based on the analysis, the purpose of this advertising is to introduce the advertising company's products and also the brands into society and to promote its identity as an enterprise following the trend and fulfilling consumer wishes. 
Meanwhile, this research wants to analyses the advertisement of Sasa Gourmet Powder. The purpose of this analysis is quite same with the previous research but this research wants to analyse in a different object and the way how to analyse this advertisement. Besides, the researchers also wanted to know about why this advertisement is made and what is the social conditions that underly the making of this advertisement. The researchers investigate Indonesian perception about the issues that appears in this product. By doing the research, the researchers also using Fairclough's (1995) three-dimensional theory of speech analysis to analyse the Sasa Gourmet Powder advertisement.

Cited from PT. Sasa Inti (Sasa) in (2020), Sasa is the first company to produce MSG in Indonesia. The name "Sasa" comes from the phrase "Sari Rasa" where "Sari" means essence, and "Rasa" means taste. Essence of Taste is the main pillar and focus of PT. Sasa Inti. It was founded by Rodamas in 1968. Pt. Sasa Inti leads the category by creating a variety of product innovations through the Sasa brand, ranging from Monosodium Glutamate (MSG), seasoning flour, coconut milk, instant seasonings, flavouring broths, and a range of sauces that provide a taste experience for all tastes and help consumers enjoy delicious, healthy, and quality food. The name "Sasa" stands for "Sari Rasa" which has the slogan (brand tagline) "Sasa Melezatkan", in accordance with its role in relaxing various flavours of cuisine.

In March 2021, Sasa issued an advertisement regarding their new package with the titled "NIKMATI GUE YANG BARU UNTUK \#NIKMATIHIDUPSEPENUHNYA". The

interesting thing about the advertisement made by Sasa is the concept of the advertisement that clarified their issues about gourmet powder that caused stupidity for people who consumed it. This is the reason why the researchers want to examine about the purpose about why this advertisement is made and the social conditions underlying the making of the advertisement.

\section{THEORETICAL FRAMEWORK}

Critical Discourse Analysis (CDA) started to become famous in the 1980s in an attempt to further study languages along with social theory. Since then, various scholars have clarified and defined CDA in various ways. Perhaps the key distinction was the relationship between speech and ideas with which the discourse interacts. It is stated by Fairclough (1992) as in (TURHAN \& Okan, 2017) that a bilateral relationship exists between social structures and discourse, because discourse influences social conventions, while social structures influence discourse. In language discussion, speech and society, Norman Fairclough is known to be one of the popular figure. TURHAN \& Okan (2017) also explained that language has a part to play in manifesting concepts and aims to gain authority over citizens through convincing them about what the language shows.

According to (Liu \& Guo, 2016), the origins of CDA theory can be understood from two perspectives. On the one hand, it retains the term "critical," as it continued to insist on the critical essence of the earlier studies; on the other hand, using "discourse analysis" instead of "linguistics" indicated that CDA is not limited to Halliday's SFL framework, as it acknowledges the concept of "discourse" from social science. According to Fairclough, who draws heavily on SFL theory and sociological theory, language is argued to be a social practise rather than a simple linguistic phenomenon that exists independently of society. As a result, he contends that language should be studied as discourse, in both spoken and written forms. Furthermore, he discusses "text," which is viewed solely as a component of people's communication processes. 
In this research, the researchers use Norman Fairclough's theory of discourse analysis in advertisement text. He said in Lestari (2020) "Discourse, and every single instance of speech practice, shall be considered at the same time as (i) a speech or written language text (ii) a discourse practice (texts production and interpretations of text), (iii) sociocultural practice". Furthermore, when going to conduct CDA studies, Fairclough distinguishes three steps or stages as well as three dimensions of discourse, which are the description stage, the interpretation stage, and the explanation stage. The description refers to the text's language property. Focus on the relation between production and interpretation discursive processes and the text. Explanation addresses the connection between processes (manufacturing and interpretation) and social conditioning. The illustration of this theory can be seen from the following picture:

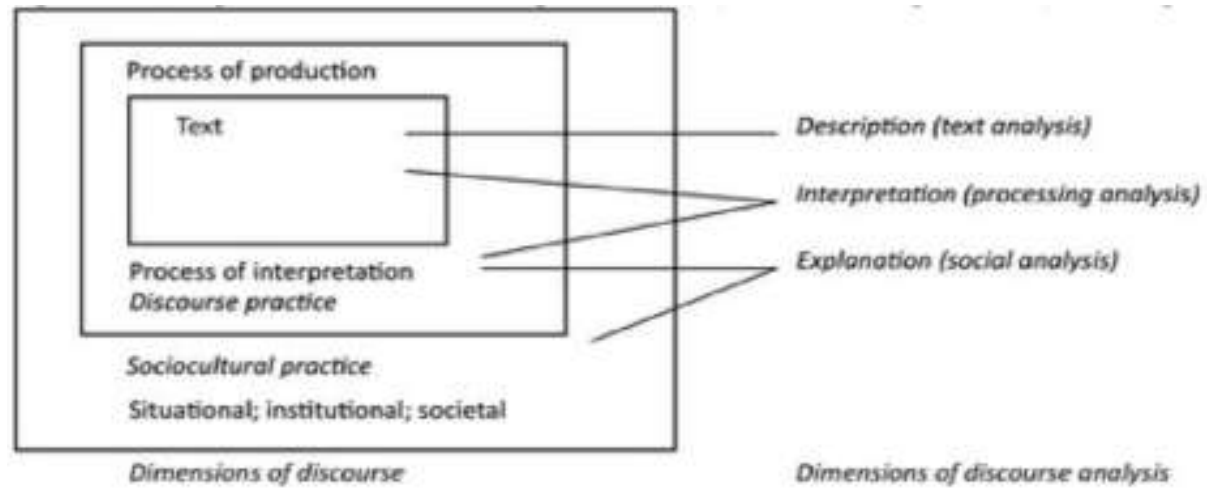

Picture 1. The Three dimensions of Discourse Analysis from (Liu \& Guo, 2016)

Advertising is one of the techniques used by people to attract attention to their services or products (Akmal et al., 2020). Currently advertising is not just used to sell products or services. Product companies are also starting to use advertising to reach their brand and convey the conceptual image, music and publicity they have inserted using advertising instead of promoting a product. Advertising also seeks to appeal to customers to purchase the products commercialised rather than others.

The first aspect that applies to verbal or visual text analyses or to both. The word "text" is used not only for linguistic characteristics such as clauses and phrases, but also for pictures, sounds, colours, songs, etc. The second-dimension concerns to the processes of manipulation and acceptance of the material. The third dimension is related to the social activities that influence development and reception, namely the historical and the social method. Regarding the first aspects, type of text and visual of Sasa advertisement were considered. Concerning the second aspect, the process of interpreting is analysed. For the last, Indonesian culture and perceptions/issues about the use of gourmet powder were analysed.

\section{METHOD}

A descriptive qualitative approach is applied in this research by using text analysis. Qualitative research is an approach for exploring and understanding the meaning individuals or groups ascribe to a social or human problem (Creswell, 2014). It means evolving questions and 
procedures, data gathered in the participant's environments, data analysis centered on information to general themes and understanding the importance of the data. Descriptive qualitative approach defines and discusses the phenomena or events in the social world, in which the author explores them from their point of view and thinks about their own perception and analyse the text on it. The qualitative approach in this paper implies that the result is analysed and descriptively elaborated. This discourse analysis is focusing on advertisements.

The source data that used in this research is a "Sasa Gourmet Powder Advertisement \#NikmatiHidupSepenuhnya (2021)" which has 29 seconds in long. The advertisement selected is available on Youtube and the relevant link is https://www.youtube.com/watch?v=- OyPxfGl2aw. The purpose of the advertisement is to give the information that Sasa has been launched their new packaging of their gourmet powder product. Besides that, Sasa also trying to clarify the issues that develop in Indonesian society about the use of gourmet powder that is harmful for health.

In collecting the data, a number of steps in the text analysis involved the researcher. The triangulation technique is the most widely used method to improve data validity (Creswell, 2014). Triangulation technique is also a method of verifying the validity of data that uses another one for checking purposes or comparison with other relevant data. Kind of triangulations are by data source (which can include persons, times, places, etc.), by method (observation, interview, document), by researcher (Investigator A, B, etc.), and also by theory. In this research, triangulation will be used for validation of the data in triangulation by the investigator.

There are several steps in analysing the data. Firstly, the selected advertisement video is observed by watching to get a comprehensive understanding. Secondly, each scene that has been identified is divided into 13 scenes. Thirdly, the scenes are analysed based on Fairclough's (1995) three-dimensional theory, which includes type of text and visual of Sasa advertisement, the process of interpreting, and Indonesian culture and perceptions/issues about the use of gourmet powder were analysed. Fourthly, the researchers draw the conclusion regarding the purpose of this research; that is to find out the purpose about why this advertisement is made and the social conditions underlying the making of the advertisement.

\section{FINDING AND DISCUSSION}

\section{Social Conditions}

There are many issues/stigmas that related to the use of dangerous gourmet powder when consumed by the body on various news portals and articles. This is widespread throughout Indonesian society. People are hesitant to use gourmet powder as an additional spice for their dishes. Because they are afraid of the dangers that are said to be caused by using gourmet powder in their dishes. Here are some news snippets and articles on the harmful uses of gourmet powders: 


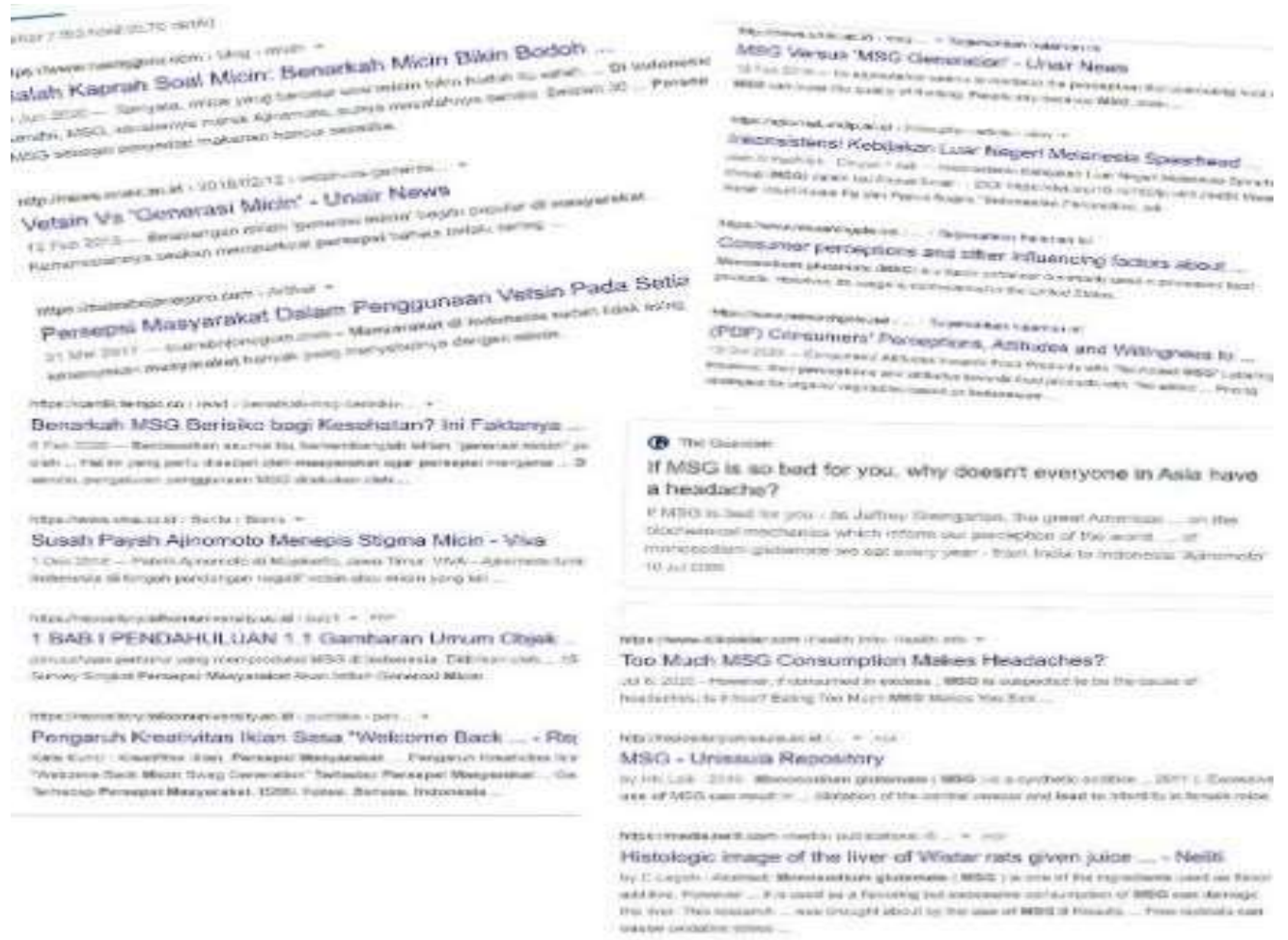

Picture. 2 News of Gourmet Powder in Google

\section{Text Analysis}

Kress (2010) in (Mumba \& Mkandawire, 2019) have been explained that text gives meaning by combining two or more modes in which each mode performs its role and purpose in the process of creating meanings. Text itself can exist or a full spoken or written message can exist. Different texts have various purposes and thus have various language features organized in different ways. In this research, because the material under this study is in the form of advertisements, the function of the text in the advertisement here is to provide information about the Sasa product. Sasa also tries to clarify the issues that have developed in Indonesia regarding the use of gourmet powders which are said to be harmful to the health of the body and also cause humans to become stupid. Researchers looked at the words and content on the video which will be analyzed in the next paragraph of discussion in a clear and trustworthy way using discourse analysis.

In this research, the researchers used a pictured scene containing words and illustrations in Sasa Gourmet Powder advertisement. The pictures were captured from the video one by one in every scene. Researchers analysed the text in detail and systematic scenes matching the videos content. So that, researchers use this advertisement to find out the meaning of the text that inserted in the pictured video. 


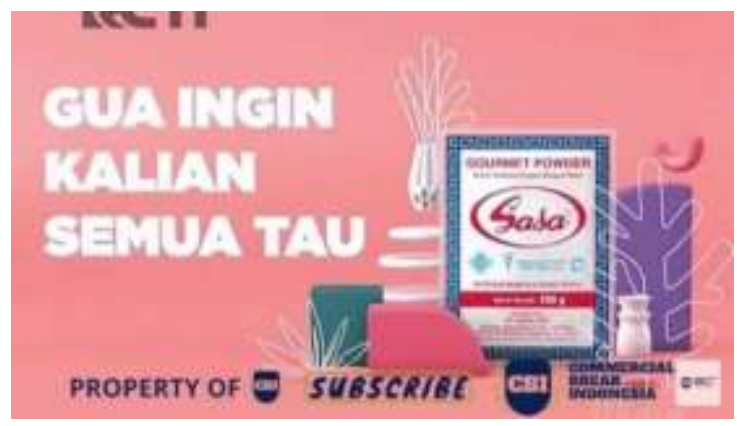

Figure 1. Captured from (Indonesia, 2021)

The advertisement begins with the appearance of Sasa Gourmet Powder product that placed between a pile of puzzle illustrations and transparent flowers. This scene shows the background of pink colour. It has a sentence as the first information of this advertisement "Gua ingin kalian semua tau" (I want you all to know). The sentence shows a statement from the first person's point of view that the person tells himself or herself (or in this case is the product) in a story. From that sentence we can find out that Sasa Gourmet Powder is trying to talk about itself.

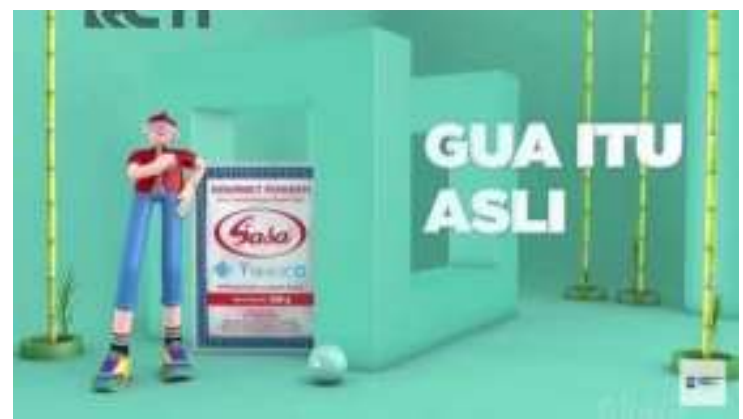

Figure 2. Captured from (Indonesia, 2021)

In the second scene comes an image of a new character of a man standing near with Sasa Gourmet Powder set in bright green colour. There is the inscription "Gua itu asli" (I'm real) next to the picture of sugar cane trees. This sentence indicates a sentence that will make the viewer ask about the meaning. While these sugar cane trees appear as a clue about the explanation of the sentence that will be discussed in the next scene. The scene of this advertisement was raised gradually to arouse interest and curiosity in the consumers.

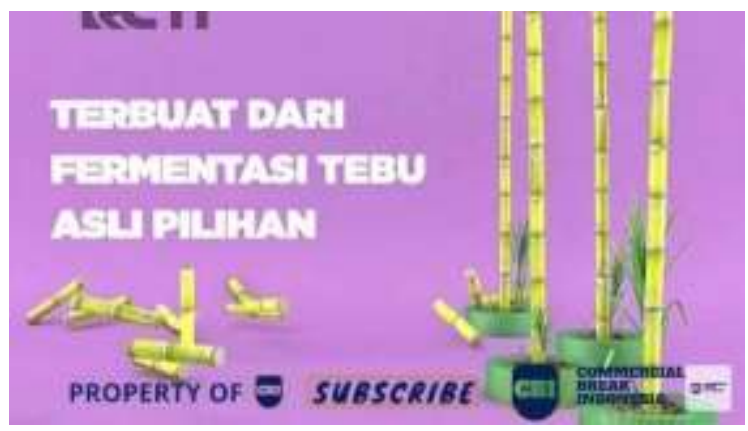

Copyright C2021 JOEPALLT

Journal of English Pedagogy, Linguistics, Literature, and Teaching 
Next, this scene contains the sentence that has no subject, it said "Terbuat dari fermentasi tebu pilihan" (Made from selected sugarcane that has been fermented). This is not a complete sentence with no subject because this statement is a continuation of the sentence in the previous scene. In this scene, it clarifies the identity of the main ingredient of Sasa Gourmet Powder which may not be known by everyone. This is confirmed by the picture of sugarcane trees on the side and pieces of sugarcane tree. So it can be indicate that Sasa Gourmet Powder is made from the extract of sugarcane trees.

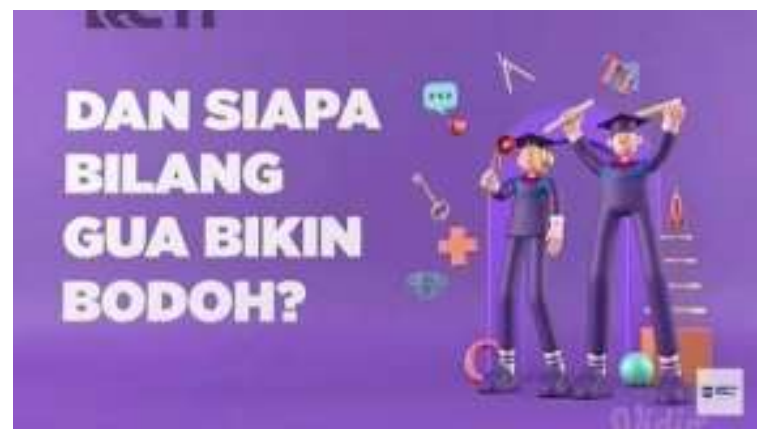

Figure 4. Captured from (Indonesia, 2021)

The fifth scene turns to the picture of graduated people in the purple background that looks getting success. This illustration is an image that contradicts to the sentence on the side. On the right side of the picture, there are two students who have just graduated while holding a diploma and surrounded by symbols of the field of study. It can be concluded that the illustration represents that these people are the ones who successfully completed their studies and are smart. It is inversely proportional to the stigma of society regarding the consumption of Sasa Gourmet Powder that can reduce the level of consumer intelligence. There is the sentence on the left side that show "Dan siapa bilang gua bikin bodoh?" (And who says I make stupid?). In this sentence, Sasa tries to raise a bad issue that is developing in the community regarding Indonesian perception of Sasa Gourmet Powder that its product makes stupidity.

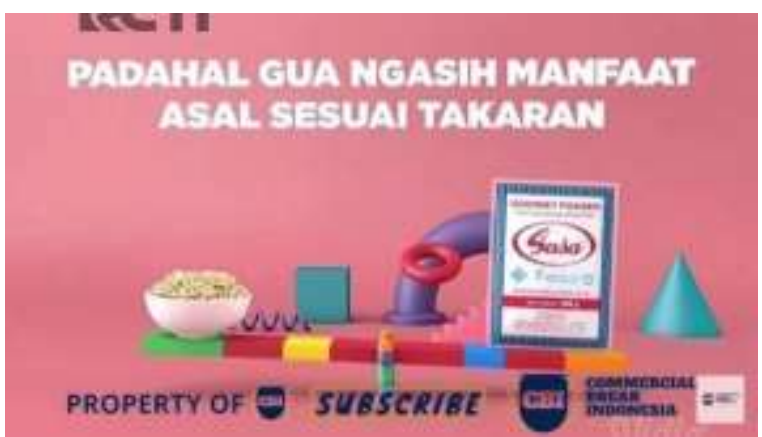

Figure 5. Captured from (Indonesia, 2021) 
The next scene shows a sentence that contains the benefits of Sasa Gourmet Powder to refute bad rumours about it. This can be seen from the beginning of the word "Padahal" (even though) as the word used to avoid statements. This is reinforced by the analogy of the balance measure drawing between a Sasa Gourmet Powder and a bowl of dish. It shows that the use of Sasa with balanced measure of dose with dishes would not be harmful.

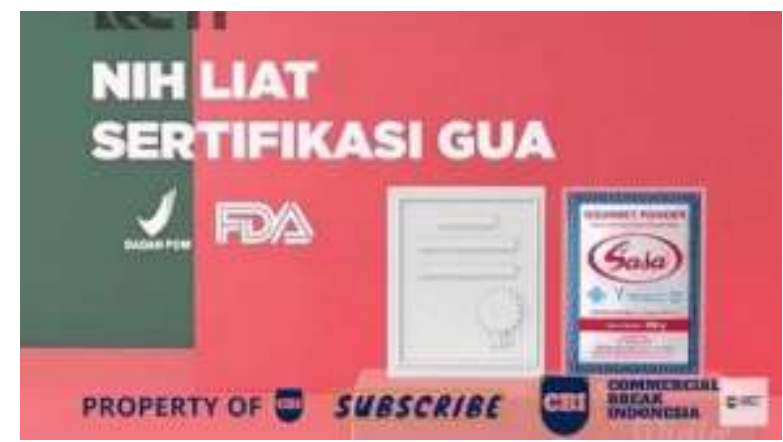

Figure 6. Captured from (Indonesia, 2021)

The sentence in this scene also tries to show the evidence from the previous statement that this product has been certified by BPOM (National Agency of Drug and Food Control) and the FDA (Food and Drug Administration). This is stated in the sentence "Nih liat sertifikasi gua" (Look at my certificate) as an imperative sentence to see the certification logo.

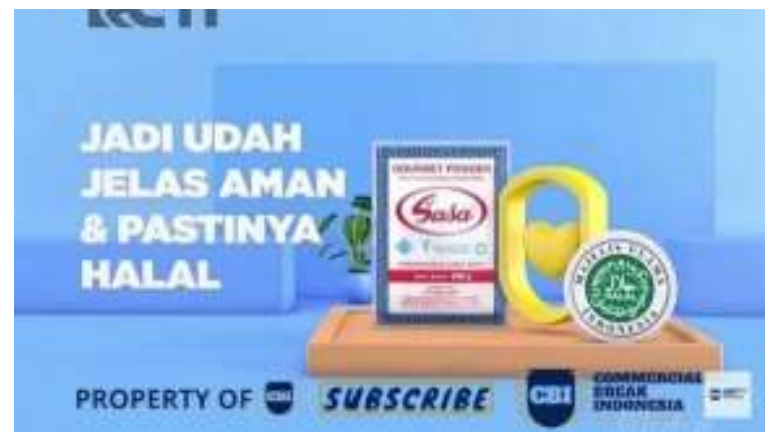

Figure 7. Captured from (Indonesia, 2021)

Then the next scene contains the continuation of the previous content. The sentence "Jadi udah jelas aman dan pastinya halal" (So it's clear it's safe and definitely halal) is in the form of additional clarification regarding product information to refute bad issues about it. The words jadi/so, jelas/obviously, pastinya/absolutely mean that Sasa Gourmet Powder used to strength the phrase aman/safe and halal/kosher. 


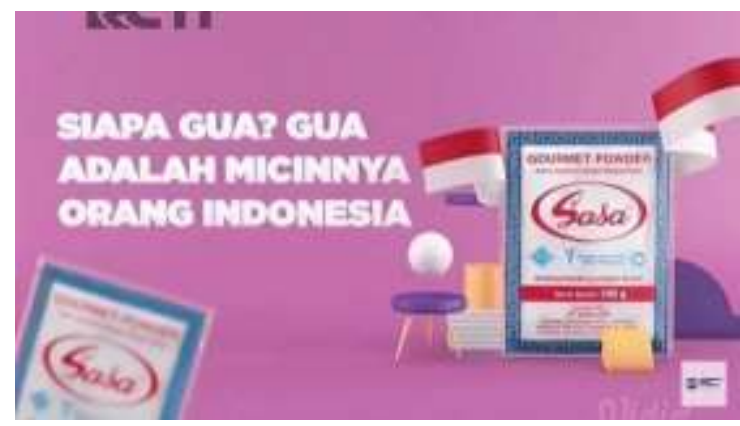

Figure 8. Captured from (Indonesia, 2021)

The eighth scenes used purple colour on its background and there are two Indonesian flag which flank the product. It is also containing the sentences "Siapa gua? Gua adalah micinnya orang Indonesia" (Who am I? I am the gourmet powder that used by Indonesian people). This scene shows the identity of its origin. The viewer will know the origin of Sasa product by seeing the Indonesian flag in the background. The sentence is a form of the emphasis sentence that Sasa Gourmet Powder is produced in Indonesia and consumed by Indonesian.

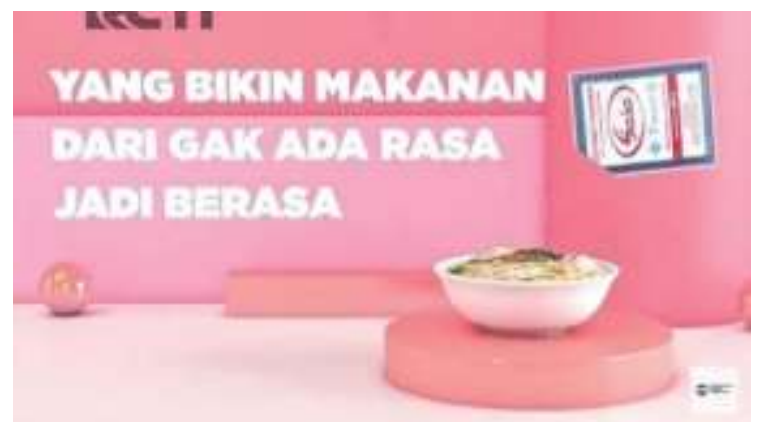

Figure 9. Captured from (Indonesia, 2021)

The ninth scenes used bright pink as their background and a bowl of dish that sprinkled by Sasa Gourmet Powder. There is a sentence that reads "Yang bikin makanan dari gak ada rasa jadi berasa" (Which made tasteless food become tasty). From this sentence, it showed the function of the product in simply way but understandable. It means that Sasa Gourmet Powder function as additional seasoning powder.

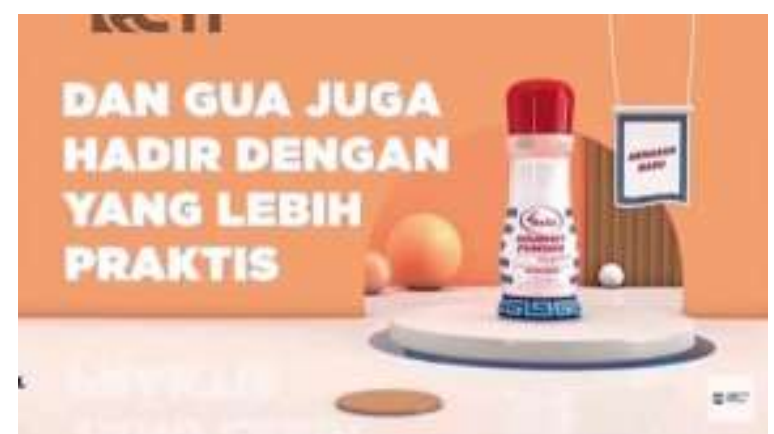

Figure 10. Captured from (Indonesia, 2021) 
On the tenth scenes, Sasa used bright orange colour as its background and there is a bottle of the newest packaging of Sasa Gourmet Powder. There is a small banner next to it that says "Kemasan Baru" (New Packaging). The sentence next to the bottle that says "Dan gua juga hadir dengan yang lebih praktis" (And I also come up with a more practical one). These sentences emphasize the presence of new packaging in the form of bottles that are more practical to use.

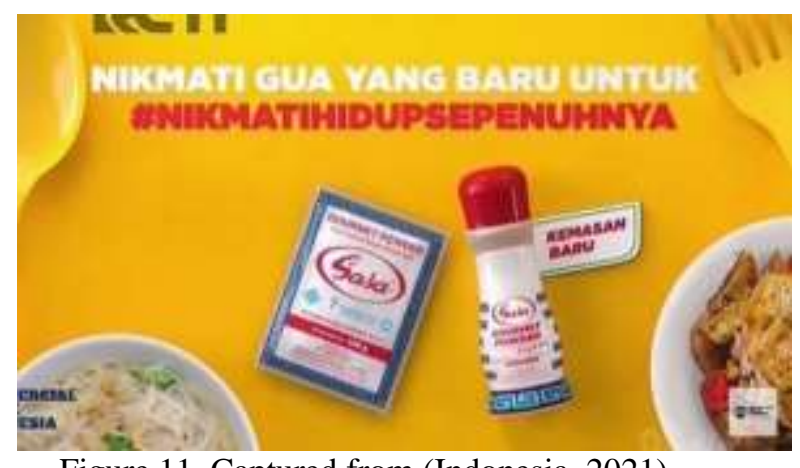

Figure 11. Captured from (Indonesia, 2021)

On the eleventh scenes, the background that used by Sasa is mixed with dark yellow and bright yellow. There is the oldest version package and a bottle as a new packaging with the sentence and tagline above "Nikmati gua yang baru untuk \#NIKMATIHIDUPSEPENUHNYA" (Enjoy the new me for

\#ENJOYLIFETOTHEFULLEST). It represented that the new package of Sasa would give the positive vibes of the product as a punchline to remove the issues about the consumption of gourmet powder which causes stupidity. Instead, by using Sasa products, consumers are expected to be able to enjoy life to the fullest better.

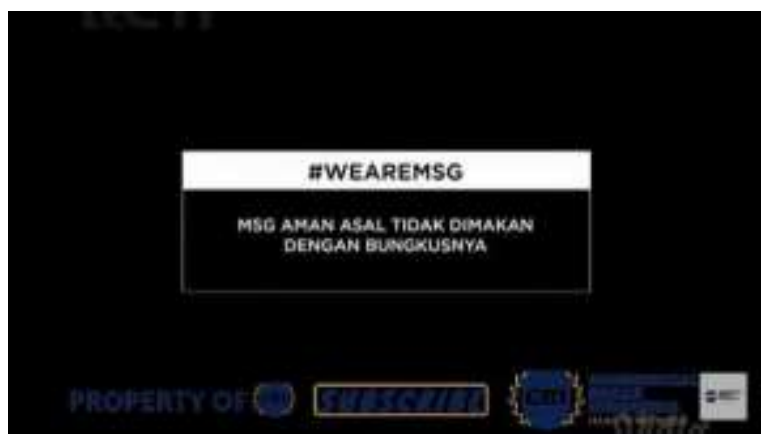

Figure 12. Captured from (Indonesia, 2021)

On the twelfth scenes, Sasa used black as the background as a sign that the advertisement is over. In addition, Sasa also gave its final punchline which reads "\#WEAREMSG MSG, aman asal tidak dimakan dengan bungkusnya" (\#WEAREMSG MSG, 
is safe as long as it is not eaten with the packaging). It means that Sasa once again emphasized that the use of MSG (Monosodium Glutamate) / gourmet powder is safe for consumption. This statement is used to equate the public's perception that the use of Sasa is safe. It is accompanied by figurative sentences that are focused on emphasizing the preceding statement. Because packaging cannot be consumed and is dangerous if eaten, the public will assume that the statement of MSG is safe to be true.

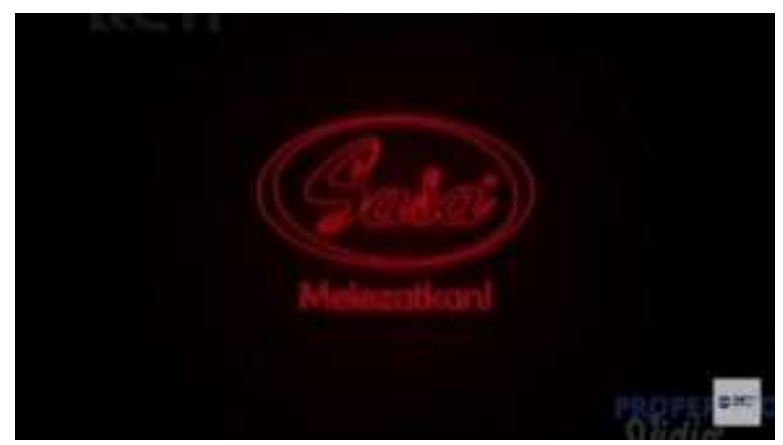

Figure 13. Captured from (Indonesia, 2021)

The advertisement was closed with Sasa company logo with the black background and bright red font colour. The purpose of this scene is clearly to promote Sasa brand which include their slogan "Melezatkan" (Flavour).

\section{CONCLUSION AND SUGGESTION}

In the previous chapter the discourse analysis of the Sasa Gourmet Powder advertisement has been described and explained. From the discussion above, it can be concluded that discourse is used in advertising to analyse the language use of text. The discussion includes the use of one unit's language, social conditions and other elements. In this research, texts, images and social aspects are the elements which build the discourse previous chapter. Each discourse has its own aim. This advertisement naturally aims to bring the company's new packaging product.

In addition to advertise their products, Sasa Gourmet Powder was trying to clarify their issue that has been spread in the society. Through this advertisement Sasa want to show the fact of the issue that the MSG product does not cause stupidity. Sasa explained Sasa explained through the statements and visuals in their advertisement that its MSG products are safe to consume as long as it is within reasonable limits of use. Sasa Gourmet Powder products havealso been certified safe and halal. So, it is hoped that consumers will not have to worry about consuming Sasa Gourmet Powder.

After all the data research was found and the conclusion was made, the researcher gives suggestion for the reader who reads this research. For other researchers who is going to analyse this research could analyse more deeper in different sights. For the reader who is ordinary people, they must consider what things they can get from the mass media, be it information or advertisements. Do not be easily provoked and must be able to see things from various points of view and rely on scientific analysis. 


\section{REFERENCES}

Akmal, S., Jarjani, J., \& Farida, I. (2020). The Discourse of Propaganda in Traveloka's YouTube Advertising Videos. Indonesian Journal of EFL and Linguistics, 5(1), 175. https://doi.org/10.21462/ijefl.v5i1.235

Creswell, J. W. (2014). Research Design. In SAGE Publications (Vol. 66).

Indonesia, C. B. (2021). Iklan Sasa Gourmet Powder \#NikmatiHidupSepenuhnya (2021). https://www.youtube.com/watch?v=-OyPxfGl2aw

Lestari, N. D. (2020). Discourse Analysis of Shopee "12.12. Birthday Sale" Advertisement. Journal of Literature, Languages and Linguistics, 69(1995), 34-42. https://doi.org/10.7176/j1ll/69-05

Helmie, J., \& Syafrudin, E. L. (2019). Semiotic Analysis of Five Famous Streetwear Trademarks, 257(Icollite 2018), 124-127. https://doi.org/10.2991/icollite-18.2019.26

Liu, K., \& Guo, F. (2016). A Review on Critical Discourse Analysis. Theory and Practice in Language Studies, 6(5), 1076. https://doi.org/10.17507/tpls.0605.23

Mumba, C., \& Mkandawire, S. B. (2019). The Text-based Integrated Approach to Language Teaching: Its Meaning and Classroom Application. Multidisciplinary Journal of Language and Social Sciences Education, 2(1), 123-143.

PT. Sasa Inti (Sasa). (2020). Tentang kami| SASA. https://www.sasa.co.id/about-us

Sukamto, K. E., \& Kartikawangi, D. (2012). Sebuah Kajian Komunikasi dan Bahasa terhadap Iklan TV Produk " CITRA." 1, 1-13.

Turhan, B., \& Okan, Z. (2017). Critical Discourse Analysis of Advertising: Implications for Language Teacher Education. International Journal of Languages' Education, 1(Volume 5 Issue 4), 213-226. https://doi.org/10.18298/ijlet.2301 